\title{
ANALISIS SISTEM SOSIAL-EKOLOGI LADA PUTIH PROVINSI KEPULAUAN BANGKA BELITUNG
}

\author{
Mahra Arari Heryanto dan Adi Nugraha \\ Departemen Sosial Ekonomi Pertanian, Fakultas Pertanian Universitas Padjadjaran \\ email: mahra.arari@unpad.ac.id
}

\begin{abstract}
ABSTRAK
Lada putih merupakan komoditas perkebunan yang seluruhnya dikembangkan oleh perkebunan rakyat di Provinsi Kepulauan Bangka Belitung. Penurunan harga lada putih yang cukup drastis di tingkat petani menjadi persoalan yang dihadapi oleh petani, hal ini menandakan persoalan sosial dalam bidang ekonomi yang berimplikasi kepada persoalan ekologi, yaitu penurunan produktivitas. Hasil penelitian menunjukan bahwa Sistem sosial dan sistem ekologi dalam usahatani lada putih membentuk umpan balik (feedback loop) yang sangat banyak, sehingga sistem sosial dan ekologi tidak bisa dipisahkan. Produksi lada putih, keputusan penanaman lada dan sistem kolektif adalah tiga unsur utama dengan kompleksitas tertinggi dalam sistem sosial-ekologi lada putih. Rekayasa sosial (kelembagaan) yang mengarah kepada penguatan sistem kolektif (kelompok) perlu banyak dilakukan bersamaan dengan insentif teknologi pasca panen yang memadai agar keberlanjutan komoditas lada putih dapat terjaga, baik secara sosial maupun ekologi.
\end{abstract}

Kata kunci: Keberlanjutan, Sistem Sosial, Sistem Ekologi, Ekonomi, Lada Putih

\begin{abstract}
White pepper is a plantation commodity which is developed by smallholder in the Bangka Belitung Province. Declining price of white pepper at farm level is a problem for the farmers, this indicates a social problem in economic that has implication ecologically, decrease of yield productivity. The research showed that social systems and ecological systems in white pepper farming establish many feedback loops, so that the social and ecological systems could not be separated. White pepper production, pepper planting decisions and the collective system are the three main elements which have highest complexity in the social-ecological system of white pepper. Social engineering (institution) through the strengthening of the collective (group) action system needs to be developed in line with post-harvest technology policy in order to create the sustainability in the white pepper commodity, both socially and ecologically.
\end{abstract}

Keywords : Sustainability, Social System, Ecological System, Economy, White Pepper 


\section{PENDAHULUAN}

Lada (Piper nigrum L) adalah komoditas non-migas yang cukup strategis bagi Indonesia di dunia internasional. Indonesia berkontribusi 14\% terhadap seluruh produksi lada dunia dan $15 \%$ dari perdagangan lada di pasar internasional. Peran tersebut adalah yang terbesar kedua di dunia setelah dominasi Vietnam dengan kontribusi produksi dan perdagangan lada dengan kontribusi lebih dari $30 \%$ produksi dan perdagangan dunia ${ }^{1}$. Provinsi Kepulauan Bangka Belitung merupakan salah satu sentra produksi lada putih terbesar di Indonesia (38\% produksi) selain Lampung dengan produk lada hitamnya (Perkebunan, 2016).

Lada putih merupakan komoditas perkebunan utama yang banyak dikembangkan di Provinsi Kepulauan Bangka Belitung selain komoditas karet dan kelapa sawit. Usahatani komoditas lada di Provinsi Kepulauan Bangka Belitung seluruhnya dilakukan oleh masyarakat atau dikuasai oleh pekebun rakyat (Perkebunan, 2016), berbeda dengan kelapa sawit yang sebagian dimiliki oleh perkebunan besar, baik milik negara maupun swasta ${ }^{2}$.

Keberadaan sektor pertanian di Bangka

Belitung tidak dapat dipisahkan dari kondisi lingkungan sebagai daya dukung utama pembangunan pertanian termasuk di dalamnya kehidupan sosial yang mencakup aktivitas ekonomi dan aktivitas sosial yang dilengkapi dengan berbagai artefak teknis atau teknologi. Aktivitasaktivitas yang dilakukan oleh manusia

\footnotetext{
${ }^{1}$ Diolah dari data FAOStat tahun 2018
}

sebagai agen, baik sosial, ekonomi maupun teknologi dalam jangka pendek maupun jangka panjang memiliki dampak terhadap lingkungan (Folke, 2006).

Sektor pertanian sebagai kolaborasi dari berbagai aktivitas sosial, ekonomi dan teknologi sebagai sistem pangan bagi yang melibatkan manusia memiliki keterkaitan yang sangat erat dengan lingkungan. Dampaknya, sistem pertanian di era modern banyak menghasilkan polusi yang berdampak kepada keberlangungan hidup manusia baik secara langsung maupun tidak langsung (Meadows, Meadows, \& Randers, 1972; Stephens, Jones, \& Parsons, 2018).

Secara konseptual, sistem sosial-ekologi (SSE) meliputi praktek-praktek budaya dan tradisional yang mempengaruhi interaksi dinamis dan kompleks antara manusia dan lingkungannya. Sistem sosial dan sistem ekologi adalah sistem kompleks yang bersifat adaptif yang disebut kompleks karena memiliki banyak bagian dan keterkaitan di antara bagian tersebut; dan terdapat struktur umpan balik (feedback loop) yang memberikan kemampuan kepada bagianbagian untuk mengubah cara bertahan dalam lingkungan yang berfluktuasi. Pemahaman terhadap interaksi antara manusia dengan ekosistemnya yang kompleks dapat dimulai dari gejala dan perilaku yang timbul di permukaan (Marten, 2001; Mukwada, Taru, \& Chingombe, 2015).

Lada putih merupakan komoditas pertanian yang akan menjadi fokus dalam

\footnotetext{
2 Provinsi Kepulauan Bangka Belitung Dalam Angka Tahun 2017
} 
tulisan ini. Sebagai sistem pertanian, sistem komoditas lada putih memiliki kompleksitas yang tinggi baik dari sistem sosial maupun ekologinya. Keberlanjutan sistem yang kompleks dibangun dari pondasi masyarakat, budaya, ekologi dan biologi yang kuat dan harmonis (Holling, 2003). Keberlanjutan ekonomi yang diperoleh dari sistem pasar merupakan modal penting dalam menggerakan ekonomi petani, namun apakah keberlanjutan ekonomi tersebut didukung oleh keberlanjutan ekologi dalam jangka panjang? Unsur-unsur sosial dan ekologi apa saja yang menjadi titik ungkit dalam pengembangan agribisnis lada putih? Jawaban dari pertanyaan tersebut merupakan tujuan dari penelitian ini, yaitu untuk melakukan suatu analisis yang mendalam dan komprehensif tentang bagaimana hubungan keberlanjutan ekonomi mempengaruhi keberlanjutan ekologi, begitu juga sebaliknya keberlanjutan ekologi mempengaruhi keberlanjutan ekonomi. Hasil dari analisis tersebut diharapkan dapat memberikan kontribusi empiris terhadap pengembangan konsep sistem sosial-ekologi dan pembangunan berkelanjutan di negara berkembang berbasis sektor pertanian.

\section{METODE PENELITIAN}

Metode penelitian yang digunakan adalah desain kualitatif. Metode kualitatif menyajikan data yang kaya akan kehidupan nyata situasi masyarakat, selain itu juga lebih mampu menangkap dan memahami suatu perilaku dalam konteks yang lebih luas (de Vaus, 2002). Analisis kualitatif pada dasarnya bersifat non-linier untuk memahami suatu sistem yang bekerja dalam jangka panjang secara holistik dan komprehensif

(Creswell, 2009; Holling, 2003).

Keterkaitan antar unsur-unsur ekologi dan unsur-unsur sosial dalam sistem komoditas lada memerlukan pemahaman yang holistik, komprehensif dan jangka waktu yang lama, sehingga diperlukan suatu alat analisis yang relevan agar diperoleh suatu pengetahuan baru mengenai pembangunan pertanian yang berkelanjutan khususnya pada komoditas lada di Provinsi Kepulauan bangka Belitung.

Pembangunan merupakan suatu sistem sosial-ekologi yang di dalamnya terdapat hubungan yang sangat kompleks, baik antara manusia dengan lingkungan, manusia dengan manusia maupun antar unsur di dalam lingkungan itu sendiri. Keberlanjutan sistem sosial-ekologi dalam sektor pertanian memiliki hubungan yang erat antara sistem sosial ekonomi dan sistem ekologi. Keberlanjutan disini diartikan sebagai suatu proses yang dapat terus berlangsung (Hjorth \& Bagheri, 2006), proses ini merupakan kombinasi dari persoalan ekologi, persoalan sosial, dan persoalan ekonomi yang saling terintegrasi (Holling, 2003). Bagaimana hubungan antara keberlanjutan ekonomi dan ekologi tersebut saling mempengaruhi dan bagaimana implikasinya terhadap sistem sosialekologi dalam pembangunan pertanian menjadi fokus dalam penelitian ini. Untuk mengetahui hal tersebut, komoditas lada (Pipper nigrum L.) menjadi objek penelitian karena dalam satu rantai sistem komoditasnya memiliki kompleksitas yang saling terkait antara aspek ekologi, aspek sosial, dan aspek 
ekonomi. Daya saing lada menjadi dapat ditingkatkan apabila keberlanjutan pengembangan komoditas lada dapat berjalan dengan baik mulai dari hulu sampai ke hilir (Yuhono j.t., 2007).

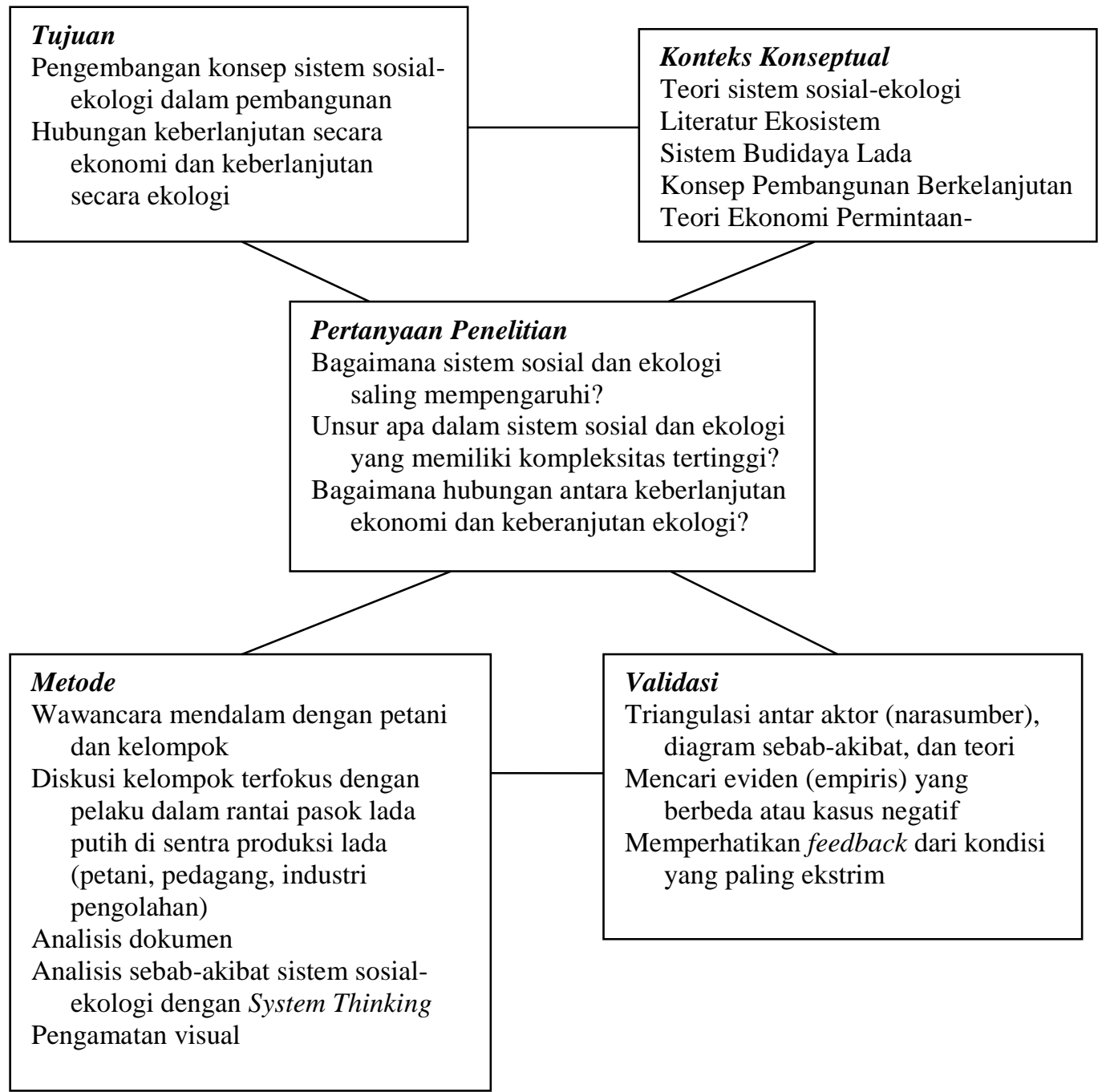

Gambar 1. Kerangka Penelitian

Pengumpulan data dalam metode

kualitatif dilakukan dengan cara

observasi dan wawancara secara tidak

terstruktur atau semi terstruktur, studi dokumen dan literatur, serta pengamatan visual yang memiliki makna terhadap fokus kajian (Creswell, 2009), dalam hal ini yang terkait dengan sistem komoditas lada. Aktor-aktor yang menjadi sumber data adalah para pelaku (agen) baik individu maupun kelompok atau lembaga dalam sistem rantai pasok lada yang ada
Bangka Belitung mulai terdiri dari agenagen sebagai berikut: sektor hulu (penyedia sarana produksi, petani penangkar benih, petani produksi, kelompok tani, Asosiasi Petani Lada Indonesia/APLI), pedagang atau sektor hilir (pedagang pengumpul desa, pedagang pengumpul besar, eksportir, Asosiasi Eksportir Lada Indonesia/AELI), lembaga penyuluhan dan pemerintah (petugas penyuluh lapangan/PPL, Dinas Pertanian dan 
Perkebunan, Badan Perencanaan

Pembangunan Daerah/Bappeda,

Kementerian Pertanian), lembaga riset

(Badan Pengkajian Teknologi

Pertanian/BPTP, akademisi) dan lembaga

perbankan (Bank Indonesia).

Pengumpulan data dilakukan pada tahun

2018 di beberapa daerah sentra produksi

lada putih di Kabupaten Bangka Selatan

dan kota Pangkal Pinang sebagai pintu

saluran pemasaran lada putih ke luar

daerah Bangka Belitung. Selain itu, Kota

Pangkal Pinang ibu kota provinsi juga merupakan pusat pemerintaahan daerah dan beberapa lembaga perdagangan dan lembaga riset komoditas lada.

Data yang diperoleh kemudian dianalisis dengan menggunakan pendekatan cara berpikir sistem (system thinking).

Pendekatan system thinking merupakan pendekatan yang mengenali hubungan saling bergantung (interdependent) dan berkaitan (interrelated) dari unsur-unsur dalam suatu sistem. Pendekatan berpikir sistem (system thinking) menganut paradigma bahwa suatu perubahan (perilaku atau dinamika) dimunculkan oleh suatu struktur (unsur-unsur pembentuk yang saling bergantung/interdependent). Selanjutnya, hubungan unsur-unsur yang saling bergantung itu merupakan hubungan sebab akibat umpan balik (feedback loop) bukan hubungan sebab akibat searah dan merupakan proses yang berlanjut (on going process) bukan potret-potret sesaat. Umpan balik tersebut bekerja secara simultan di dalam struktur diagram sebab akibat yang mengandung banyak aktivitas inidividu (kompleksitas tinggi), tetapi apabila tidak terdapat umpan balik atau feedback maka kompleksitas dinamika tidak dapat digambarkan (Senge, 1990; Sterman, 2000).

Validasi dalam penelitian kualitatif berbeda dengan penelitian kuantitatif, terdapat beberapa langkah yang digunakan untuk memastikan akurasi dari hasil yang diperoleh dalam penelitian ini (Creswell, 2005), di antaranya:

- Triangulasi sumber data yang berbeda dengan memeriksa berbagai kejadian yang membangun kepada suatu koherensi

- Klarifikasi hasil temuan dengan berbagai studi yang dilakukan dan data yang tersedia

- Memunculkan informasi yang tidak sesuai untuk mengimbangi informasi yang diperoleh, diskusikan informasi yang bertolak belakang berdasarkan kredibilitas sumber informasi.

- Berada di lapangan untuk waktu yang lama untuk memperolah pemahaman yang mendalam atas fenomena yang terjadi dan menentukan kredibilitas dari narasumber (informan) yang sebenarnya.

- Gunakan narasumber ahli dari eksternal untuk memperoleh masukan informasi sebelum menarik suatu kesimpulan.

Akurasi dari setiap data yang diperoleh sangat diperlukan untuk memperoleh suatu kebenaran dari fenomena yang diteliti, diperlukan teknik validasi yang mampu mengeliminasi bias-bias yang mungkin terbentuk dalam penelitian. Validasi adalah komponen yang tidak dapat dihilangkan dalam suatu penelitian untuk menghasilkan kesimpulan yang 
benar, sesuai dengan kenyataan atau realitas. Validasi merupakan proses membangun kepercayaan dari model peneltian yang dilakukan, dalam berfikir sistem salah satunya adalah validasi struktur yang di dalamnya terdapat putaran umpan balik (feedback loop) yang dilakukan setelah terbentuknya struktur diagram sebab-akibat atau dalam pemodelan kualitatif beerada tahapan evaluasi model (Luna-Reyes \& Andersen, 2003; Sterman, 2000).

Selanjutnya data yang diperoleh tersebut diterjemahkan ke dalam suatu bentuk struktur model kualitatif yang disebut "cara berpikir sistem" atau system thinkning dan dianalisa berdasarkan putaran umpan balik (feedback loop) yang terdapat pada struktur diagram sebab akibat (causal loop diagram/CLD) (Sterman, 2000). Tahap pertama ini merupakan proses konseptualisasi yang di dalamnya terdiri atas pendefinisian masalah dan pembentukan konseptualisasi sistem, yaitu fokus kepada model mental, dunia nyata dan data dokumen tertulis yang secara verbal dideskripsikan oleh feedback loop dalam CLD (Luna-Reyes \& Andersen, 2003). Dokumen yang tertulis dan model mental merupakan dinamika perilaku yang dapat selalu berubah dilihat dari perjalanan waktu atau behavior over time (BOT) (Forrester, 1992).

Tahap kedua adalah formulasi, pada tahap ini dilakukan pendalaman struktur yang lebih detil dan pemilihan nilai parameter yang terkait. Unsur-unsur yang terdapat dalam struktur CLD bisa berupa parameter yang memiliki ukuran tertentu dan juga unsur-unsur yang bersifat kualitatif (Luna-Reyes \& Andersen, 2003).

Tahap ketiga adalah pengujian, bagian ini merupakan validasi dari tahapan penelitian sebelumnya, termasuk data yang diperoleh pada awal pengumpulan data. Tahap pengujian terdiri atas perilaku model dan evaluasi model. Mekanisme yang paling dasar dari pengujian perilaku model adalah dengan cara referensi (reference mode), salah satunya dengan menggunakan data statistik. Kemudian evaluasi model dilakukan dengan verifikasi struktur oleh pakar yang memiliki keahlian atau bagian dari sistem yang digambarkan (LunaReyes \& Andersen, 2003). Referensi yang digunakan dalam sistem komoditas lada putih adalah data luas lahan, produksi dan produktivitas lada putih dalam kurun waktu 15 tahun terakhir. Selanjutnya para tokoh tani, ketua asosiasi (petani, pedagang), pimpinan pemerintah daerah yang menangani lada (Dinas Perkebunan) dan petugas penyuluh lapangan (PPL), dan para peneliti lada adalah pakar yang memiliki pengetahuan dan pengalaman yang terlibat langsung dalam sistem komoditas lada.

\section{HASIL DAN PEMBAHASAN}

Pendekatan sistem sosial-ekologi (SES) merupakan kombinasi secara teori dan empiris oleh para ahli yang meliputi ilmu ekologi, ilmu ekonomi dan ilmu sosial. Secara fundamental, hubungan manusia dengan lingkungan tidak diterima sebagian sistem yang mempertentangkan sasaran dengan proses perjalanannya. Lebih jauh, dinamika umpan balik (feedback) antara sistem manusia sebagai 
satu komponen dan sistem ekologi tidak dapat dipandang sebagai bagian yang terpisah. Lingkup kajian ini merupakan pendekatan yang holistik yang mengintegrasikan berbagai disiplin dan kompleksitas (Berkes, 1993).

Pembahasan dalam kajian ini dibedakan menjadi interaksi antar unsur dari sistem sosial dengan sistem ekologi.

Pemahaman yang holistik terhadap proses dari ketersalinghubungan dalam kompleksitas yang terjadi menjadi fokus utama dalam pembahasan dan analisis yang dijelaskan dalam suatu diagram sebab-akibat dengan pendekatan system thinking.

\section{Konseptualisasi Persoalan Sistem Komoditas Lada: Dinamika Produksi, Produktivitas dan Harga}

Persoalan lada putih yang paling menonjol pada tahun 2018 mengenai harga beli yang rendah di tingkat petani. Harga yang diterima petani tidak memberikan insentif bagi petani untuk membudidayakan tanaman lada.

Kondisinya berbeda dengan era tahun 1980-1990an dimana harga lada saat itu saat menjanjikan dan memberikan keuntungan berlipat dan kesejahteraan yang sangat baik kepada para petani di Bangka Belitung.
"Harga lada anjlok sekali. Dulu orang Bangka kaya-kaya. Kulkas dibeli untuk taruh baju. Mesin cuci dibeli untuk menaruh baju. Karena harga lada sempat mencapai Rp 200.000 per kilogram" ujar Jauhari salah satu petani lada Bangka Belitung ${ }^{3}$.

"Harga lada putih Bangka mengalami pasang-surut. Tahun 1998 mencapai $R p$ 100.000 per kilogram, tetapi kemudian anjlok menjadi tak lebih dari Rp 20.000 per kilogram. Sejak saat itu, penanaman lada tak lagi dilirik masyarakat ${ }^{4}$,

Berdasarkan perilaku harga ekspor lada, diperoleh informasi bahwa pada masa tahun 1980an sampai 2000an harga lada tercatat berfluktuasi sangat tinggi, senada dengan penyampaian petani dan informasi dari para narasumber yang terkait dengan lada putih. Perilaku flutuasi harga yang cukup tinggi menunjukan tingginya dinamika yang terjadi. Jika dilihat berdasarkan pola harga ekspor lada (Gambar 2), diketahui bahwa dalam waktu 30 tahun (tahun 1980 sampai 2010) harga lada mengalami kenaikan sebanyak tiga kali dan penurunan sebanyak dua kali dengan perbedaan yang cukup tajam (harga tertinggi lima kali lipat dari harga terendahnya).

\footnotetext{
${ }^{3}$ Artikel di Kompas.com pada tanggal 28/06/2018 jam 18:58 WIB dengan judul "Harga Lada Jatuh, Petani Curhat ke Jokowi", https://nasional.kompas.com/read/2018/06/28/185 84591/harga-lada-jatuh-petani-curhat-ke-jokowi.
}

\footnotetext{
${ }^{4}$ Artikel di Kompas.com pada tanggal 08/02/2010 jam 05/05 WIB dengan judul "Lada Putih Bangka Tergusur", https://nasional.kompas.com/read/2010/02/08/050 50255/Lada.Putih.Bangka.Tergusur.
} 

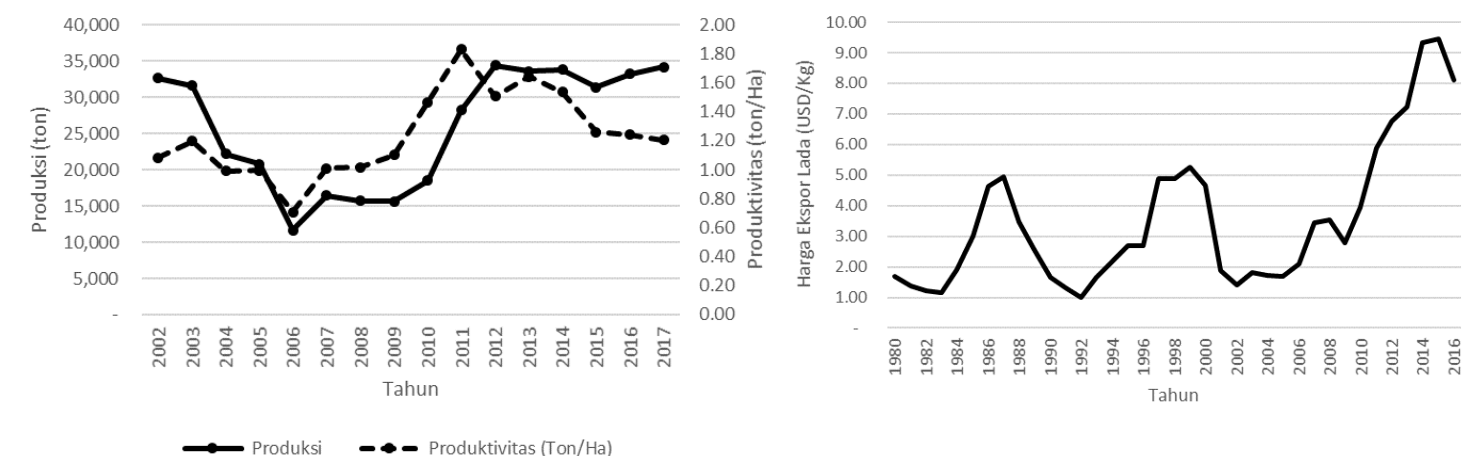

Sumber: diolah dari Provinsi Kep. Bangka Belitung Dalam Angka (BPS) 2002-2017 dan FAOStat 2018

Gambar 2. Produksi dan Produktivitas Lada Putih tahun 2002-2017 dan Harga Ekspor Lada Putih tahun 1980-2016 di Provinsi Kep. Bangka Belitung

Setelah tahun 2010, harga lada terus merangkak naik dan mencapai puncaknya pada tahun 2015. Harga lada pada tahun 2015 tersebut memecahkan rekor dari dari tahun-tahun sebelumnya karena mengalami lonjakan yang luar biasa. Petani menerima harga beli dari pedagang rata-rata 150.000 rupiah, bahkan ada yang mencapai 170.000 rupiah untuk satu kilogram lada putih di tahun $2015^{5}$, sementara harga jual ekspor berkisar antara 7 sampai 8 dolar AS (Amerika Serikat) per kilogram.

Bila dibandingkan antara harga ekspor lada dan produksi, secara historis harga ekspor lada kurang dari 2 dolar AS per kilogram tidak memberikan insentif bagi petani, penurunan produksi pada tingkat harga tersebut menunjukan keengganan petani untuk bertanam lada. Keengganan petani tersebut sangat beralasan karena harga lada pada titik impas menurut penuturan petani adalah 50.000 rupiah per kilogram. Senada dengan analisis yang dilakukan oleh pemerintah daerah Provinsi Bangka Belitung dimana titik

\footnotetext{
${ }^{5}$ http://bangka.tribunnews.com/2015/04/29/hargalada-tembus-rp-170-ribu-per-kilogram
}

impas atau biaya produksi lada ptuih kering adalah 52.500 rupiah per kilogram ${ }^{6}$. Harga lada putih di tingkat petani pada tahun 2018 berada pada kisaran 50.000 per kilograam lada kering. Implikasinya, nilai tersebut tidak memberikan insentif bagi petani karena biaya produksi lebih besar nilai yang diterima, yang berarti secara ekonomi petani tidak memperoleh keuntungan dari usahatani lada. Harga yang diharapkan petani dan memberikan insentif apabila lada putih dibeli oleh pedagang pada kisaran 80.000-100.000 per kilogram.

\section{Formulasi Struktur: Sistem Sosial- Ekologi yang Kompleks}

Kompleksitas dapat dilihat dari sudut pandang interaksi antara manusia dengan manusia yang saling bergantung satu sama lain (sistem sosial dan ekologi). Secara khusus dalam sistem pangan pertanian (agri-food system), kompleksitas secara global didorong oleh permintaan konsumen akan pemenuhan bahan makanan, dan secara lokal ditentukan oleh tatakelola kelembagaan

6 Laporan Master Plan Komoditas Lada Putih, Dinas Pertanian, Perkebunan, dan Peternakan Prov. Kepulauan Bangka Belitung, tahun 2015 
yang ada di daerah produksi pertanian (Crona \& Bodin, 2013). Aktivitas pertanian pada prakteknya melibatkan manusia sebagai unsur sosial, sumber daya alam dan lingkungan sebagai unsur ekologi, dan transaksi ekonomi sebagai unsur ekonomi dan teknologi sebagai unsur artifak teknis (Heryanto, Supyandi, \& Sukayat, 2016).

Secara akumulatif, semua aktivitas yang memberikan dampak kepada lingkungan bila ditelusuri berasal dari banyak aktivitas individu-individu, termasuk di dalamnya sistem pertanian. Perubahan lingkungan yang sangat cepat telah mendorong konsep pembangunan berkelanjutan yang ekologis berkembang sangat pesat, termasuk di dalamnya terdapat suatu konsep "ketahanan" (resilience) ekologi (Marten, 2001).

Konsep tersebut mengalami perkembangan dengan kompleksitas perubahan lingkungan yang semakin cepat dan dinamis. Kemudian, perubahan lingkungan pada akhirnya melahirkan berbagai upaya untuk memahami hubungan antara proses sosial dan ekologi yang secara keilmuan berada pada ranah yang berbeda. Diperlukan suatu kelembaman atau daya "pegas" yang dikenal dengan istilah "ketahanan" untuk mengantisipasi perubahan yang begitu cepat dan dinamis tersebut, yaitu kemampuan sistem sosial-ekologi untuk meredam gangguan yang terjadi tanpa membalikan atau melemparkan residu kepada bagian yang lainnya (Cote \& Nightingale, 2012).

Perubahan dalam sistem sosial, baik dari aspek modal sosial maupun ekonomi dalam praktek nyata tercermin oleh berbagai aktivitas manusia dalam mengelola dan memanfaatkan sumberdaya alam dengan berbagai pengetahuan dan keterampilan yang dimilikinya. Kompleksitas ini terjadi pada tingkat lokal (desa) dimana para petani berperan besar sebagai pengambil keputusan yang berada pada posisi produsen ditinjau dari sistem pangan yang bersifat transaksional ekonomi (Crona \& Bodin, 2013).

\section{Sistem Ekologi}

Pada kasus lada putih, penggunaan sumberdaya alam yang dimaksud adalah budidaya lada putih pada lahan usahatani yang dikelola oleh petani. Permintaan pasar akan pasokan lada putih mendorong kelompok tani untuk melakukan penanaman dan budidaya lada putih. Harga beli lada putih di tingkat petani merupakan insentif yang paling efektif bagi petani untuk berproduksi, hal ini tampak pada tahun 2002 sampai 2006, dimana harga lada yang rendah (sekitar Rp 25.000-an per kilogram atau harga di pasar internasional USD 2 per kilogram) dan dianggap tidak menguntungkan bagi petani. Para petani mengeluhkan rendahnya harga lada putih tidak sebanding dengan pengorbanan selama tiga tahun masa tanaman lada tumbuh sampai dapat menghasilkan buah lada yang siap diolah. Masa pertumbuhan pada tiga tahun setelah hari tanam dalam istilah budidaya dikenal dengan TBM (tanaman masa tumbuh), setelahnya dikenal TM (tanaman menghasilkan) yang rata-rata menghasilkan lada putih kering antara 3 sampai 4 kilogram per 
pohon $^{7}$. Sementara itu dikenal TT

(tanaman tidak menghasilkan) atau tanaman tua dengan produktivitas yang sangat rendah atau hanya $10 \%$ atau 0,25 0,30 kilogram lada putih kering dari setiap pohon. Para petani lada rata-rata akan mengganti tanamannya apabila tanaman telah memasuki usia 7 tahun sejak dari penanaman karena dianggap sudah tidak produktif lagi.

Para petani di Bangka Belitung sebagian besar melakukan budidaya lada dengan luasan rata-rata 0,5 hektar per petani dengan jumlah 1.000 batang pohon lada. Petani dengan modal yang besar akan bertanam lada sampai dengan 2 hektar lahan atau lebih dari 3.000 pohon, sementara petani dengan modal kecil berkisar antara 500-750 pohon saja. Bagi masyarakat di Bangka Belitung, bertanam lada merupakan kebiasaan yang telah berlangsung lama secara turun temurun dan merupakan bagian dari budaya. Kebudayaan merupakan hubungan antara individu (manusia) dengan ekologi sosial lingkungannya (Oishi \& Graham, 2010) dan lada sebagai komoditas pertanian sudah sejak lama diusahakan oleh sebagian masyarakat di wilayah Bangka dan Belitung. Proses ini secara berulang menjadi pendorong roda ekonomi masyarakat dilihat dari aspek produksi dan produktivitas (feedback loop R1 dan R2 pada Gambar 3).

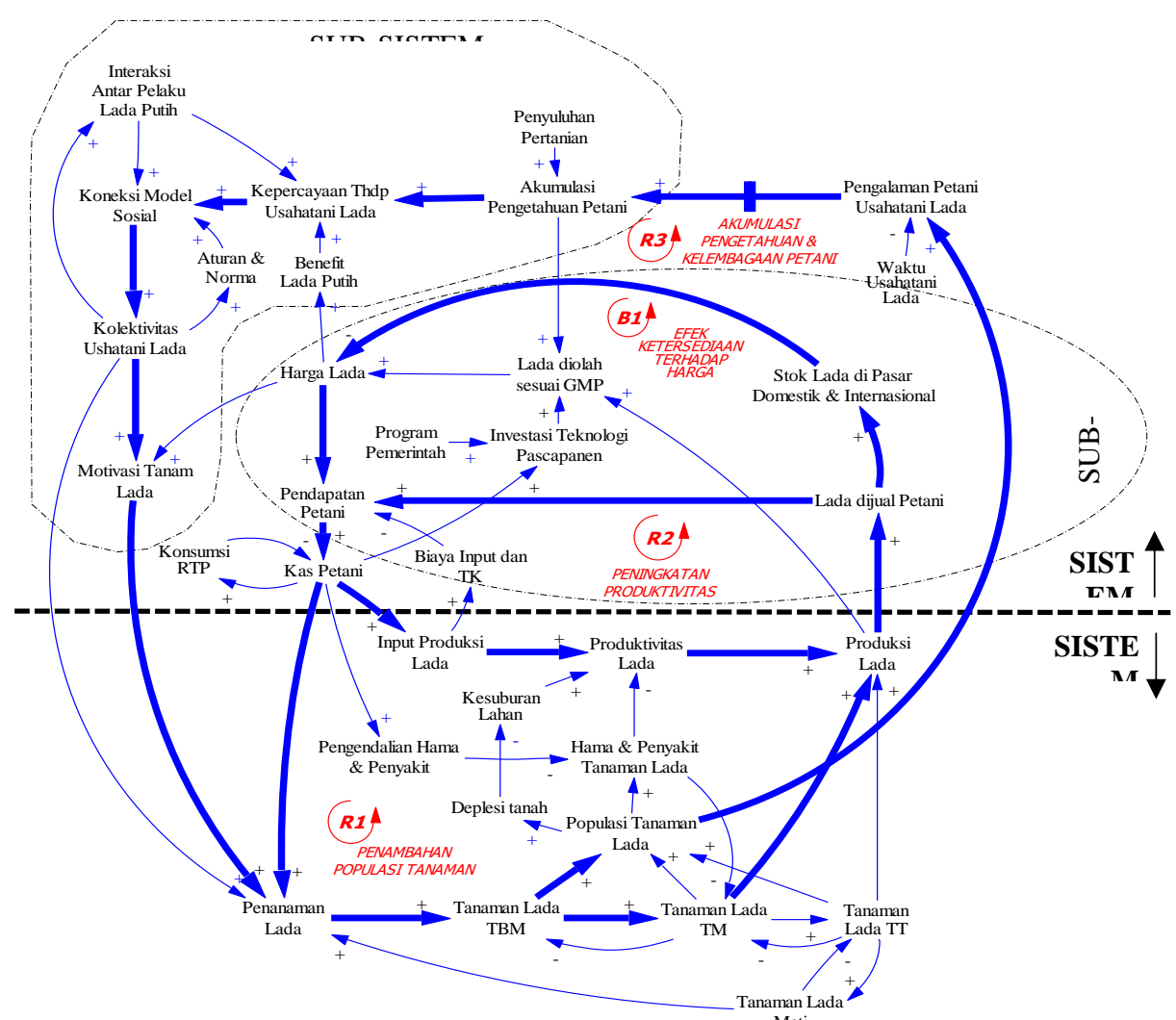

Gambar 3. Formulasi Struktur Diagram Sebab-Akibat (Causal Loop Diagram / CLD) Sistem Komoditas Lada di Bangka Belitung

\footnotetext{
7 Laporan Master Plan Komoditas Lada Putih, Dinas Pertanian, Perkebunan, dan Peternakan Prov. Kepulauan Bangka Belitung, tahun 2015
} 
Secara ekologi beberapa petani menyadari bahwa produktivitas lada masih belum memenuhi potensi yang seharusnya. Hal ini disebabkan oleh gangguan OPT (organisme pengganggu tanaman) merupakan salah satu faktor penghambat rendahnya produktivitas lada di Bangka Belitung. Penyakit utama yang menyerang pertanaman lada di Bangka Belitung adalah penyakit kuning yang disebabkan oleh asosiasi serangan nematoda dan jamur dari faktor tanah. Tanaman lada yang terkena penyakit kuning akan terhambat pertumbuhannya, daun menguning dan kaku namun tidak layu (Daras \& Pranowo, 2009).

Selain disebabkan faktor hama, penurunan produktivitas lada adalah menurunnya kualitas lahan yang sudah sejak lama ditanami lada. Hal ini diungkapkan oleh para tokoh tani yang sudah puluhan tahun mengusahakan lada. Kondisi tanah yang kurang baik menurunkan produksi biji lada secara perlahan, sehingga masih jarang disadari oleh petani. Penuturan ini diungkapkan oleh beberapa petani yang melakukan perbaikan kondisi tanah melalui peningkatan unsur hara dan perbaikan struktur tanah ternyata mampu meningkatkan pertumbuhan biji lada pada saat panen.

Faktor kesuburan lahan dan hama penyakit atau OPT merupakan unsur ekologi yang terdapat dalam sistem komoditas lada. Keduanya muncul sebagai akibat dari perilaku sosial atau keputusan petani sebagai menusia. Begitu pula penanganannya, diperlukan campur tangan manusia agar proses alam (kesuburan tanah dan OPT) tidak merugikan seccara ekonomi. Pola interaksi antara unsur ekologi dan sosial tersebut menunjukan bahwa sistem sosial-ekologi tidak dapat dipisahkan dalam sektor pertanian. Sistem sosial ekologi adalah sistem yang dinamis dan berubah secara terus menerus merespon tekanan secara internal maupun eksternal (Schlüter, Hinkel, Bots, \& Arlinghaus, 2014).

Berdasarkan kasus lada, unsur produktivitas dan produksi merupakan aspek ekologi yang berasal dari keputusan sosial atau manusia. Produktivitas yang mengalami penurunan akan mengurangi pendapatan secara ekonomi, karena dengan korbanan biaya yang sama, tetapi masukan dari penerimaan penjualan lada semakin berkurang. Perubahan aspek ekologi mempengaruhi perubahan pada aspek sosial, begitu juga sebaliknya.

\section{Sistem Sosial (Ekonomi)}

Pendekatan sub-sistem ekonomi dilihat dari hukum ekonomi permintaan dan penawaran. Secara sistem, efek ketersediaan lada di pasar internasional merupakan umpan balik negatif yang bergerak berlawanan arah dengan jumlah stok, apabila terdapat banyak ketersediaan lada di pasar internasional, maka harga akan mengalami tekanan (feedback loop B1: efek ketersediaan terhadap harga). Fluktuasi harga dan ketersediaan lada di pasar terjadi dalam hitungan tahun, berbeda dengan sayuran yang berfluktuasi lebih cepat. Lada merupakan komoditas yang cukup lama untuk disimpan, berdasarkan penuturan petani lada dapat disimpan sampai dengan 2 tahun, dengan teknik penyimpanan dan tingkat kekeringan lada yang baik. 
Persepsi petani terhadap isu kualitas dianggap sebagai upaya para pedagang untuk menjatuhkan harga beli di tingkat petani Walaupun isu kualitas sering kali dianggap sebagai penghambat oleh petani lada dalam aspek pasca panen lada, tetapi pada faktanya dilihat dari aspek standar kualitas internasional, mutu lada yang dihasilkan para petani di Bangka Belitung masih berada di bawah standar, seperti kadar air, kandungan benda asing dan bakteri (Usmiati \& Nurdjannah, 2007). Diperlukan perbaikan teknologi pasca panen agar dapat memenuhi standar internasional (IPC: International Pepper Community), sehingga harga jual lada dapat meningkat di pasar internasional (Kemala, 2006; Usmiati \& Nurdjannah, 2007). Namun demikian, pengembangan teknologi memerlukan biaya yang cukup besar yang sult dijangkau oleh para petani lada skala kecil dengan luasan 0,5 hektar per petani. Diperlukan sistem kolektif dalam pengembangan teknologi ini yang berimplikasi kepada peran dan fungsi kelembagaan. Pemerintah daerah telah berupaya dengan pengembangan teknologi pasca panen melalui peran kelompok tani, namun daya ungkit untuk upaya tersebut masih belum dirasakan oleh sebagian besar petani. Bantuan teknologi pasca panen dengan biaya besar memakan anggaran yang besar pula sehingga masih sangat terbatas pada beberapa kelompok tani saja.

\section{Sistem Sosial (Modal Sosial)}

Tingginya modal sosial yang di kalangan petani merupakan modal dasar secara sosial yang dapat dimanfaatkan dalam pemanfaatan teknologi secara kolektif. Sistem kolektif yang baik ini dapat meningkatkan partisipasi para petani dalam program pemerintah yang secara kelembagaan ditranslasikan kepada fungsi nkelompok tani. Modal sosial memiliki peran yang positif dalam pembangunan masyarakat perdesaan (Koutsou, Partalidou, \& Ragkos, 2014).

Modal sosial adalah kepercayaan, bersifat resiprokal (berbalasan), dan berhubungan dengan relasi sosial (Carroll, 2001).

Proses interaksi yang sering dan kuat menumbuhkan modal sosial di antara individu dalam waktu yang lebih singkat (Koutsou et al., 2014). Proses perulangan kebiasaan bertanam lada secara sosial terjadi pada feedback loop R3, dimana akumulasi pengalaman dan pengetahuan bertanam lada menjadi motivasi masyarakat untuk bertanam lada. Semakin baik harga lada di tingkat petani (lebih dari 100.000 rupiah per kilogram), maka daya dorong untuk bertani lada secara sosial menjadi lebih besar. Begitu juga sebaliknya, apabila harga lada rendah (kurang dari 70.000 rupiah per kilogram), maka daya dorong tersebut berbalik menjadi keengganan maysarakat untuk mengusahakan lada di lahannya, terlebih lagi pada saat penelitian (tahun 2018) harga lada putih kering di petani hanya berada pada kisaran 50.000an rupiah per kilogram. Situasi ini berulang dalam kurung waktu 2 sampai 4 tahun, dimana terdapat waktu-waktu tertentu harga lada rendah dan tinggi, bergantung banyaknya keersediaan di pasar internasional. Proses perulangan dari proses usahatani yang berulang-ulang ini menumbuhkan modal sosial di antara petani yang ditunjukan oleh semangat "korsa" para petani untuk menanam lada bagi beberapa petani dengan semagat dan 
loyalitas tinggi walaupun harga lada tidak terlalu menguntungkan.

\section{Pengujian}

Pengujian struktur terdiri atas perilaku model dan evaluasi model. Perilaku model dilihat dari referensi data statistik yang membandingkan antara harga ekspor lada dengan produktivitas lada. Kedua unsur tersebut (produktivitas dan harga lada) merupakan dua unsur dari sub-sistem yang berbeda, produktiivitas adalah unsur ekologi, sedangkan harga lada adalah unsur sosial.

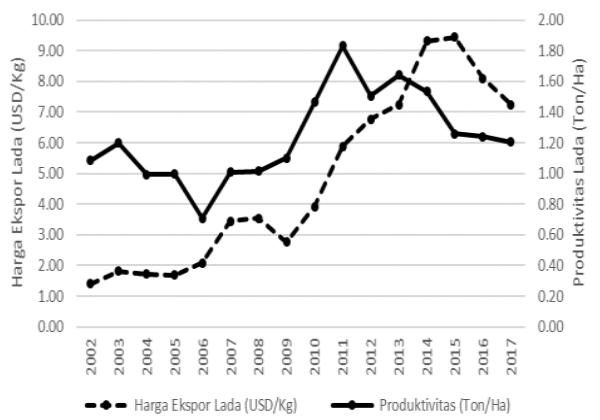

Gambar 4. Perbandingan Harga Lada dan Produktivitas Lada di Provinsi Bangka Belitung

Merujuk kepada gambar di atas (Gambar 4) tampak bahwa harga yang tinggi akan berpengaruh kepada tingkat produktivitas petani. Pada saat harga lada putih tinggi (di atas 100.000 rupih per kilogram atau setara harga lada ekspor 6 dolar AS per kilogram), para petani akan merawat tanaman ladanya lebih intensif dibandingkan pada saat harga rendah (kisaran 50.000 rupih per kilogram atau setara harga 2-3 dolar per kilogram). Pada harga petani lada putih, tidak hanya intensif merawat tanamannya, tetapi juga memiliki motivasi yang tinggi untuk melakukan penanaman lada di lahan yang dimilikinya. Keinginan untuk bertanam lada tumbuh seiring dengan tingginya harga lada.

Namun demikian sebaliknya, pada saat harga lada putih rendah, para petani memiliki motivasi yang rendah untuk bertanam lada, bahkan pada saat tanaman lada habis masa produktifnya (lada TT), petani tidak akan membudidaya lada untu penanaman berikutnya. Alih-alih menanam lada kembali, tanaman lada yang ada pun dibiarkan begitu saja tanpa perawatan yang baik menurut penuturan para petani akibatnya banyak bermunculan OPT atau hama dan penyakit yang menurunkan produktivitas tanaman lada. Proses banyaknya OPT dan menurunnya kualitas lahan yang berdampak kepada produktivitas lada (sistem ekologi) dalam kasus petanian sebagai akibat dari hukum pasar secara ekonomi adalah konsekuensi yang tidak diharapkan (untended cosequency). Aktivitas manusia berimplikasi kepada lingkungan yang kemudian direspon secara alamiah oleh unsur-unsur ekologi dalam bentuk menurunnya daya dukung ekologi (Marten, 2001).

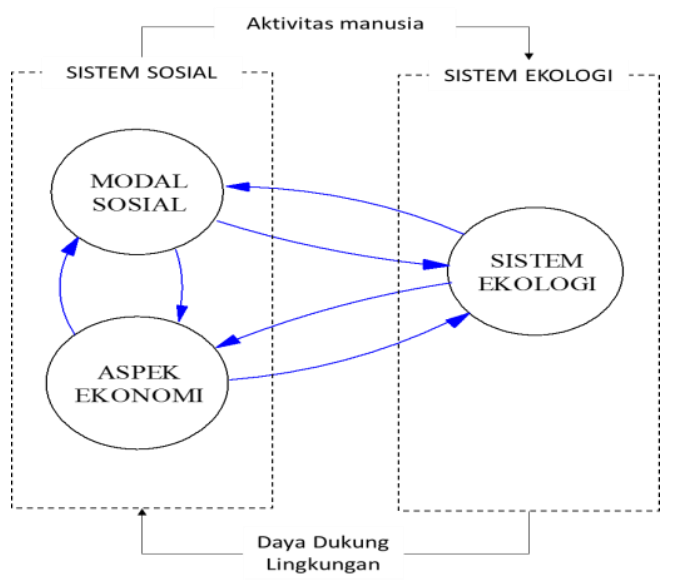

Gambar 5. Interaksi Sistem Sosial dan Ekologi Lada Putih (adaptasi dari Marten, 2001) 
Keberlanjutan yang seharusnya terbentuk menjadi terhambat akibat interaksi unsur sosial dan ekologi. Keputusan-keputusan petani yang bersifat ekonomi berimplikasi kepada sistem ekologi yang bersifat alamiah. Dibutuhkan keputusan yang bersifat kolektif untuk menciptakan suatu sistem yang menguntungkan baik itu sistem sosial maupun ekologi, kekuatan sumberdaya lokal, baik itu sumberdaya manusia maupun lingkungan dapat menjadi suatu alternatif perubahan (Ramakrishnan, 2007). Terlebih lagi komoditas lada putih telah menjadi budaya pertanian yang sedapat mungkin dipertahankan dalam konteks lokal untuk menghidupi masyarakat dan penggerak roda ekonomi, sementara itu dalam konteks global memiliki daya saing yang tinggi di pasar dunia.

\section{Keberlanjutan Ekonomi dan Keberlanjutan Ekologi}

Keberlanjutan ekonomi dalam usahatani lada putih sangat ditentukan oleh keputusan ekonomi petani lada itu sendiri sebagai feedback atau respon dari sistem ekologi. Berdasarkan analisis di atas, keberlanjutan ekonomi dalam usahatani lada putih memiliki kerentanan lebih tinggi dibandingkan keberlanjutan ekologi. Suksesi ekologi sebagai proses biologis berjalan lambat karena bersifat sistematis alamiah dalam mecapai keseimbangan ekologi (Marten, 2001). Keputusan ekonomi yang tepat dari para petani dalam rangka merespon dinamika harga (ekonomi) menjadi kunci bagi sistem ekologi untuk merespon atas perubahan yang terjadi, salah satunya adalah dengan meningkatkan kualitas lada putih agar memiliki daya saing yang tinggi di pasar global.
Pada akhirnya, hampir tidak mungkin memisahkan aspek ekonomi dari aspek sosial dan lingkungan. Ditinjau dari perspektif kompleksitas sistem sosial, diperlukan ontologi yang mendalam dalam mengenali ketersalinghubungan antara ekonomi, pemerintahan, dan sosial kemasyarakatan (Walby, 2007). Terdapat banyak hubungan sosial yang terbentuk baik antar manusia maupun manusia dengan lingkungannya, yang pada akhirnya memberikan dampak yang besar pada kedua sistem. Sistem sosial (individu) dan ekologi memiliki ketahanan atau resilience untuk menjalankan fungsinya walapun terdapat banyak tekanan yang tida diharapkan (Marten, 2001). Pemahaman terhadap dinamika lingkungan secara komprehensif dalam sistem sosialekologi memiliki peran besar dalam membangun konsep pembangunan berkelanjutan (Cote dan Nightingale, 2012).

\section{KESIMPULAN DAN IMPLIKASI}

Sistem sosial dan sistem ekologi dalam usahatani lada putih membentuk suatu umpan balik (feedback loop) yang sangat banyak, artinya antara sistem sosial dan ekologi tidak bisa dipisahkan. Produksi lada putih, keputusan penanaman lada dan sistem kolektif adalah tiga unsur utama dengan kompleksitas tertinggi dalam sistem sosial-ekologi lada putih. Ketiga unsur tersebut berdasarkan analisis sistem memiliki daya ungkit yang besar untuk mempengaruhi sistem sosialekologi komoditas lada putih secara keseluruhan.

Intervensi terhadap unsur yang memiliki daya ungkit besar dapat dilakukan untuk 
memperbaiki kekurangan sistem pembangunan pertanian lada putih. Rekayasa sosial yang mengarah kepada penguatan sistem kolektif (kelompok) perlu banyak dilakukan bersamaan dengan insentif teknologi pasca panen yang memadai agar lada putih yang dihasilkan petani dapat bersaing di pasar dunia. Insentif lainnya dapat dikembangkan setelah komoditas lada memiliki daya saing yang tinggi di pasar internasional, seperti pengelolaan ketersediaan (stok) melalui resi gudang dan sistem pembiayaan rantai nilai lada dalam satu sistem rantai pasokan hulu sampai ke hilir.

\section{DAFTAR PUSTAKA}

Berkes, F. (1993). Traditional Ecological Knowledge in Perspective. In J. T. Inglis (Ed.), Traditional Ecological Knowledge, Cocepts and Cases (pp. 1-9). Ottawa, Canada: International Program on Traditional Ecological Knowledge and International Development Centre.

Carroll, T. F. (2001). Social Capital, Local Capacity Building, and Poverty Reduction. Social Development.

Cote, M., \& Nightingale, A. J. (2012). Resilience thinking meets social theory: Situating social change in socio-ecological systems (SES) research. Progress in Human Geography, 36(4), 475-489. https://doi.org/10.1177/03091325 11425708

Creswell, J. W. (2005). Research Design. https://doi.org/10.4135/97818492 08956
Creswell, J. W. (2009). Research Design: Qualitative, Quantitative and Mixed Approaches (3rd Edition). Research Design: Qualitative, Quantitative, and Mixed Methods Approaches. https://doi.org/10.2307/1523157

Crona, B., \& Bodin, O. (2013). Adapting institutions: Governance, complexity and socio-ecological resilience. In E. Boyd \& C. Folke (Eds.), Adapting institutions: Governance, complexity and socio-ecological resilience (Vol. 31). New York: Cambridge University Press. https://doi.org/10.1068/c460wr1

Daras, U., \& Pranowo, D. (2009). Kondisi Kritis Lada Putih Bangka Belitung dan Alternatif Pemulihannya. Jurnal Litbang Pertanian, 28(1), 1-6.

de Vaus, D. A. (2002). Surveys in Social Research (5th editio). Crows Nest NSW: Allen \& Unwin.

Folke, C. (2006). Resilience: The emergence of a perspective for social-ecological systems analyses. Global Environmental Change, 16(3), 253-267. https://doi.org/10.1016/j.gloenvch a.2006.04.002

Forrester, J. W. (1992). Policies, decisions and information sources for modeling. European Journal of Operational Research, 59(1), 42-63. https://doi.org/10.1016/03772217(92)90006-U

Heryanto, M. A., Supyandi, D., \& 
Sukayat, Y. (2016). Model

Perilaku Petani Dalam Adopsi

Sistem Usahatani Padi Organik:

Paradoks Sosial-Ekonomi-

Ligkungan. Sosiohumaniora, 18(2), 149-154.

Hjorth, P., \& Bagheri, A. (2006).

Navigating towards sustainable development: A system dynamics approach. Futures, 38(1), 74-92. https://doi.org/10.1016/j.futures.2 005.04 .005

Holling, C. S. (2003). The backloop to sustainability. In F. Berkes, J. Colding, \& C. Folke (Eds.), Navigating Social-Ecological Systems, Building Resilience for Complexity and Change (p. 417). Cambridge: Cambridge University Press. https://doi.org/10.1007/s13398014-0173-7.2

Kemala, S. (2006). Strategi

Pengembangan Sistem Agribisnis Lada Untuk Meningkatkan Pendapatan Petani. Litbang Pertanian, 5(1), 47-54.

Koutsou, S., Partalidou, M., \& Ragkos, A. (2014). Young farmers' social capital in Greece: Trust levels and collective actions. Journal of Rural Studies, 34, 204-211. https://doi.org/10.1016/j.jrurstud.2 014.02 .002

Luna-Reyes, L. F., \& Andersen, D. L. (2003). Collecting and analyzing qualitative data for system dynamics: Methods and models. System Dynamics Review, 19(4), 271-296. https://doi.org/10.1002/sdr.280
Marten, G. G. (2001). Human Ecology. Basic concepts for sustainable development. https://doi.org/10.4324/97818497 76028

Meadows, D. H., Meadows, D., \& Randers, J. (1972). Limits to Growth.

Mukwada, G., Taru, P., \& Chingombe, W. (2015). Role of SocialEcological Systems in Forest and Woodland Conservation in Zimbabwean Resettlement Areas. Journal of Asian and African Studies, 50(3), 276-288. https://doi.org/10.1177/00219096 14527906

Oishi, S., \& Graham, J. (2010). Social Ecology: Lost and Found in Psychological Science. Perspectives on Psychological Science: A Journal of the Association for Psychological Science, 5(4), 356-77. https://doi.org/10.1177/17456916 10374588

Perkebunan, D. J. (2016). Statistik Perkebunan Indonesia Komoditas Lada 2015-2017. (D. D. Hendaryati, Y. Arianto, W. K. Zuraina, E. Pudjianto, A. Udin, N. Kurniawati, ... E. Magdalena, Eds.). Jakarta: Direktorat Jenderal Perkebunan, Kementerian Pertanian RI.

Ramakrishnan, P. S. (2007). Sustainable ariculture and food security: India-China context. China Report, 43(2), 219-229. https://doi.org/10.1177/00094455 0704300211 
Schlüter, M., Hinkel, J., Bots, P. W. G., \& Arlinghaus, R. (2014).

Application of the SES framework for model-based analysis of the dynamics of socialecological systems. Ecology and Society, 19(1). https://doi.org/10.5751/ES-05782190136

Senge, P. M. (1990). The Fifth

Discipline: The Art and Practice of the Learning Organization. Performance Instruction (Vol. Rev. and u). https://doi.org/10.1002/pfi.417030 0510

Stephens, E. C., Jones, A. D., \& Parsons, D. (2018). Agricultural systems research and global food security in the 21st century: An overview and roadmap for future opportunities. Agricultural

Systems, 163, 1-6.

https://doi.org/10.1016/j.agsy.201

7.01 .011

Sterman, J. D. (2000). Business

dynamics: Systems thinking and modeling for a complex world. Management.

https://doi.org/10.1057/palgrave.j ors. 2601336

Usmiati, \& Nurdjannah. (2007).

Pengaruh lama perendaman dan cara pengeringan terhadap mutu lada putih. J. Tek. Ind. Pert., 16(3), 91-98.

Yuhono j.t. (2007). Sistem agribisnis lada. Jurnal Litbang Pertanian, 26(2), 76-81. Retrieved from http://pustaka.litbang.pertanian.go .id/publikasi/p3262074.pdf 